\title{
IFRS and Financial Performance: Study in the French Context
}

\author{
Hela Turki ${ }^{1,2}$, Senda Wali ${ }^{2}$, Zahra Tajuddin Abdelgader Ali $^{1} \&$ Mona Hassab Elrasoul Mohammed ${ }^{1}$ \\ ${ }^{1}$ College of Business, Jouf University, AlJouf, Saudi Arabia \\ ${ }^{2}$ Faculty of Economics Sciences and Management, University of Sfax, Sfax, Tunisia \\ Correspondence: HelaTurki, College of Business, King Khaled Road, Jouf University, AlJouf, Saudi Arabia. Tel: \\ 966-55-638-6581.
}

Received: November 26, 2019

Accepted: January22, 2020

Online Published: March 25, 2020

doi:10.5430/ijfr.v11n2p424

URL: https://doi.org/10.5430/ijfr.v11n2p424

\begin{abstract}
This article examines the direct and indirect impact of the IFRS mandatory adoption on the financial performance of companies. The structural equation method has been applied to all companies that belong to the CAC All tradable index for the period from 2002 to 2012. By measuring financial performance by three measures, namely the Marris ratio, the Tobin $\mathrm{Q}$ and the PER ratio, the results show that the imposition of the international standards has no direct effect on the financial performance, its effect is indirect via the cost of capital.
\end{abstract}

Keywords: IFRS, cost of capital and financial performance

\section{Introduction}

In the current economic situation characterized by a growing globalization of enterprises, as well as by continuous improvement of technology, a fundamental criterion for the success and achievement of competitiveness is the application of the appropriate accounting methods. These methods form the basis of the financial management decision-making process. The assessment of the current state of companies, the analysis of its financial information and the evaluation of its financial indicators are largely linked to the accounting standards applied.

Multiple previous works have acknowledged that the mandatory application of international IFRS standards has an impact on the financial position and performance of companies, on policies, decisions and choices of executives, on investor behavior and on the activity of financial markets. This study fed into this framework. It examines the effect of the mandatory adoption of IFRS on the financial performance of companies. In other words, it attempts to answer the following research question: Does the mandatory adoption of IFRS affect the financial performance of companies?

According to Danjou (2012) (Note 1), a good financial communication increases transparency, reduces the risk to investors and leaders and thus reduces the risk premium and the cost of capital. A lower capital cost mechanically improves the financial performance of the company and promotes the sustainability of its development.

From their share, Bushman and Smith (2001) predict that the cost of capital is one of the channels through which IFRS can affect the performance of companies. These postulates support the idea that the effect of IFRS on financial performance may be indirect, through their effects on the cost of capital. Thus, the purpose of this article is to verify the direct and indirect effect of international standards on financial performance. The indirect effect is studied by the inclusion of the mediator variable of cost of capital.

The IFRS adoption, of Anglo-Saxon origin, has resulted in several qualitative and quantitative changes that constitute a revolution in local accounting systems, particularly in continental accounting systems. Ding et al. (2007) show that France is one of the European countries whose local standards are the most different from IFRS. According to Raffounier (2007), the application of IFRS in France represents a real cultural break. It has been the subject of numerous criticisms in the Parisian square (Danjou, 2013). From then, it seemed interesting to focus on the French context.

This article is structured as follows. The first part is devoted to presenting a synthesis of the previous literature review followed by the formulation of the hypotheses tested. In the second part, the research methodology used to verify the direct and indirect impact of IFRS on financial performance is presented. The third part is devoted to the presentation and discussion of the obtained results. In conclusion, the research perspectives useful for the extension 
of this study are suggested after presentation of its main limits.

\section{Literature Review}

The study of financial performance is based mainly on two theories. The first is the theory of the portfolio according to which the best financial performance results from an optimal portfolio of risky assets that includes percentages of several securities on the market. The second is the agency theory which stipulates that the financial performance of the company reflects the results of the company as well as the efficiency of the contractual relations between the stakeholders of the company. So, financial performance is a key concept for the company and its various stakeholders. The importance of this concept has prompted many studies to examine its determinants. This part is devoted to the presentation of these studies. In other words, it presents the studies that examine the direct and indirect relationships between IFRS and financial performance.

\subsection{IFRS and Financial Performance: Direct Relationship}

The companies accounting, which is based on the application of accounting and financial standards, represents a basis for assessing the financial situation and performance of enterprises. This postulate suggests a relationship between performance and the applicable accounting repository. Several researchers have attempted to confirm this relationship empirically. These studies can be grouped into two research streams. The first focuses on the impact of IFRS on performance measures and the second focuses on the effect of these standards on the performance itself.

The impact of IFRS on financial performance measures was mainly attributed to the impact of the application of the fair value principle. By measuring performance by different ratios, Sahut and Souissi (2007), Steker and Otrusinova (2011) and Beranova and Polak (2014) showed that the measures changed after IFRS adoption with the application of this principle. In this same framework of analysis, contradictory results were found by Barneto and Gregorio (2011) and Beuren et al. (2008) which suggest that financial performance has not been affected by the adoption of IFRS. According to Barneto and Gregorio (2011), the application of fair value is neutral with respect to financial performance. However, business activity and operating margin are the two factors that contribute most to this concept.

Looking at the effect of adopting IFRS, Taiwo and Adejare (2014) show a strong and positive relationship between the IFRS adoption and financial performance. This relationship results from the reduction of the firm's costs. They state that the adoption of IFRS, through improved efficiency and productivity of firms, effectively improved the companies' performance and helped the proper allocation of resources. These results are contradictory to those of Unobong (2015) and Junior (2015).

Lainez and Callao (2000) conducted a research study examining the impact of international accounting diversity on liquidity, debt, solvency and profitability ratios and, therefore, on analysis and interpretation of financial statements at the International scale. This statistical analysis revealed that the liquidity, solvency, indebtedness and profitability situation of firms depends strongly to the accounting principles applied in the production of the financial statements. It also allows concluding that international accounting diversity represents a major handicap for the analysis and interpretation of financial information at international level and for the development of investment operations worldwide. These results show that the adoption of IFRS has reduced the level of uncertainty in the financial market.

The heterogeneity of the results found by the various researchers and the absence of a study that analyzes the impact of the IFRS adoption on the financial performance of companies in the European context shows that this issue requires more exploration in this context.

In line with the objective of the international standardization bodies and the European Union which imposed the adoption of IFRS to its member states, these standards represent a regulatory framework at the international level for the publication of financial information with better quality. This information helps in the comparability of the companies' financial statements in different countries and also to proper decision-making. Consequently, a reduction in uncertainty stemmed from the adoption of this international repository. This reduction encourages the different market participants to carry out more transactions with companies that apply these standards, thus leading to an improvement in the financial position and financial performance of these companies. As a result, a positive and significant relationship between IFRS and financial performance of companies is expected. The first hypothesis is formulated as follows.

H1: The IFRS mandatory adoption has a direct impact on the companies' financial performance.

The IFRS effect on the companies' financial performance is not necessarily direct, it can be indirect. This indirect effect is studied via the cost of capital. 


\subsection{IFRS and Financial Performance: Indirect Relationship}

The indirect relationship between IFRS and financial performance through the cost of capital breaks down into two direct relationships: the first between IFRS and the cost of capital, and the second between the cost of capital and financial performance.

Looking at the first relationship, Cuijpers and Buijink (2005) and Daske (2006) examine the consequences of voluntary adoption of IFRS on the cost of equity. They suggest that there is no significant relationship between these standards and this cost. These results validate the hypothesis that IFRS does not reduce the cost of equity, in some cases they even suggest its increase. They were explained by the low quality of the cost of equity's measure, the fact that the incentives of companies' executives to apply IFRS adequately are limited and the low comparability of intercompany financial statements following the increase of differences between the accounting practices of firms using IFRS with those firms that use local standards.

To explain this non-significant impact of the IFRS voluntary adoption on the cost of equity, Daske et al. (2012) compared companies that apply IFRS in totality with those that only refer to a few standards. They show that liquidity and capital cost do not change after the IFRS voluntary adoption. However, the mandatory adoption of the totality of IFRS is followed by an increase in liquidity and a decrease in the cost of capital, which is not the case for partial adoption. They conclude that only companies that fully adopt IFRS in the context of mandatory adoption provide better quality reporting. These authors argue that the lack of significant effects associated with the voluntary adoption and the partial adoption of IFRS is due to the non-serious and non-rigorous application of these standards. They have not been seen as a commitment to providing superior quality of financial information to investors. These results have been criticized by Kim et al. (2013) for two reasons. First, it is not easy to distinguish between companies that adopt IFRS in full and those that partially adopt them. Secondly, there is a general trend to improve the quality of reports which makes it impossible to eliminate the possibility that companies applying local standards improve the quality of their reports. By examining the impact of voluntary adoption of IFRS on the cost of capital, these authors show a significant effect regardless of the institutional factors in the countries. Similarly, Barth et al (2008) find that the adoption of the international repository is associated with a lower cost of capital. However, this effect remains linked to the solid legal application which improves the comparability of information and increases their disclosure ( $\mathrm{Li}, 2010)$.

According to the defendants of the adoption of IFRS, these standards constitute a source of reduction of information asymmetry. This reduction has the effect of mitigating the risk perceived by investors, which lowers the cost of capital.

Using a sample of listed Korean companies during the period from 2000 to 2013, Kim and Ryu (2018) examines the effect of IFRS adoption on cost of equity. These authors find a significant effect of the IFRS mandatory adoption since 2011 and they explain their results by the increased financial disclosure and the enhanced information comparability.

Lima and al. (2018), examine the relationship between IFRS adoption and cost of equity and the effect of national culture on this relationship. Based in sample of 2692 companies from 31 countries, they find that IFRS mandatory adoption decrease significantly the Cost of equity. But this result change when the effect of IFRS adoption was compromised by one or more dimensions of national culture.

Tweedie (2006) stipulates that the removal of a major investment risk, that of the fear that the various national accounting systems have not been fully understood, should allow for the reduction of the cost of capital and the opening of new opportunities for diversification and improvement of investment returns. Based on this, a significant and negative relationship between IFRS and the cost of capital is expected.

Turning to the second relationship, between the cost of capital and financial performance. The study of this relationship began by Modigliani and Miller (1958). They link the leverage (capital structure), the cost of capital and the value of the firm. Their objective was to prove that the market value of the company is independent of the capital structure. On a sample of US companies, the researchers show that the capital structure has no effect on the cost of capital. This structure does not change the value of the company and investment decisions whatever the fluctuations of financial leverage.

Later, a large number of researchers focused on the impact of the capital structure on company performance. Two main contradictory arguments have been put forward. The first is the one put forward by Jensen (1986), which stipulates that executives sometimes engage in destructive investments in the presence of Free Cash Flow (the funds remaining at the disposal of the company's managers after having financed all Profitable projects that have a positive 
net present value). This money may be non-redistributed between shareholders but used by executives in uncertain and unprofitable projects for the company. Indeed, in the presence of debt, they will be forced to engage in profitable projects that allow them to pay interest charges and to avoid bankruptcy of the company. On the contrary, the second argument put forward by Simerly and Li (2000) states that the debt logically reduces the managers' discretion over the company's resources and their ability to cope with competitive pressures. This reduction affects new and risky projects, which ensure the long-term survival of the company as R \& D (Kochhar, 1996).

Kebewar (2012), by analyzing the effect of the capital structure on the profitability of French companies, found neither a linear nor a nonlinear effect of the capital structure on profitability, whatever the size of the firm studied. However, Lahmini (2015) predicts that this effect differs depending on the nature of the debt, a negative effect of long-term debt and a positive effect of short-term debt.

The interest granted to the study of the effect of the financial structure on the profitability of the company is justified by the fact that the indebtedness represents a risky choice which can lead to the bankruptcy of the company. In fact the capital structure can apprehend the companies cost of capital. Some authors have examined the direct effect of the cost of capital on the firm's financial performance.

Pastor et al. (2008) and Tashfeen and Liton (2010) show that the theoretical cost of capital is perfectly correlated with the expected return of equities. This cost is useful in detecting the inter-temporal risk-return relationship, even if profit forecasts are poor.

For their part, Pouraghajan et al. (2012) conclude that the increase in this cost leads to an increase in financial performance. This result was attributed on the one hand to investors and suppliers of financial resources who expect appropriate returns in return for their funding and on the other hand to the company seeking to provide them with the expected rate of return on financial resources through the elimination of its needs and the increase of profitability. These results are similar to those of Swanson and Viinanen (2006) and Mohamed and Saad (2012) and contradictory to those of Rehman and Zaman (2011), Khaled and Samer (2013) and Ibrahim and Ibrahim (2015).

Due to the lack of unanimity of the theoretical as well as the empirical results for the two direct relations which make up our indirect relationship and due to the absence of a study that examines the indirect impact of IFRS on financial performance through the cost of capital, an exploration of the indirect relationship between the mandatory adoption of IFRS and financial performance is interesting.

Bushman and Smith (2001) mentioned the presence of at least three channels through which financial information can contribute to the improvement of the company's performance. The first path is the best identification of profitable projects by managers and investors, the second way is the good governance (Control of the actions of the managers and protections of the investors) and the third is the reduction of information asymmetry between investors. According to these authors, the direct improvement of these three channels improves indirectly the performance by reducing the level of risk perceived by investors to the company's activities and consequently the cost of capital. Indeed, the cost of capital is a key concept for financial experts, it is considered the most effective way in the decision-making process. Brigham and Gapenski (1996) suggest that the manager of the firm must be able to determine the optimal cost of capital and maintain it at its level to increase the value and performance of the company. It is therefore expected that a significant indirect effect of the mandatory adoption of IFRS on the financial performance of companies through the cost of capital exist. Hence, the second hypothesis formulated is the following:

H2: The mandatory adoption of IFRS has a positive indirect effect on the companies' financial performance through the reduction of the cost of capital.

\section{Research Methodology}

The purpose of this study is to analyze the direct and indirect impact of the IFRS mandatory adoption on the companies' financial performance. To study these two effects empirically, the statistical method of structural equations was applied.

\subsection{Conceptual Research Model}

Figure 1 presents the conceptual model of this study. It schematizes the two hypotheses formulated. 


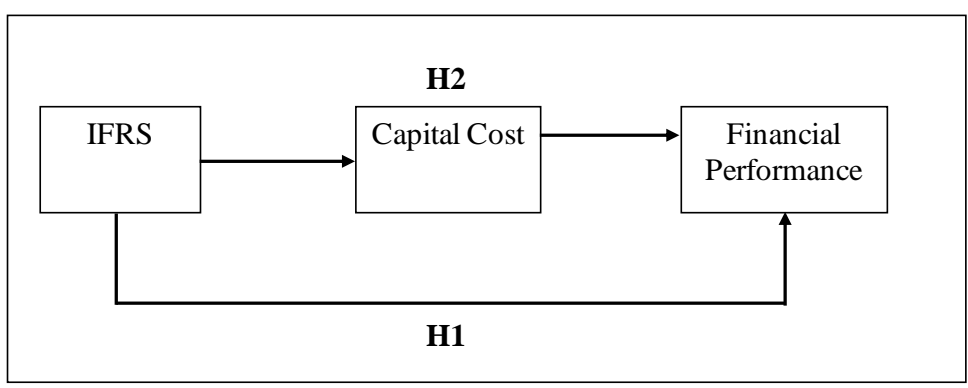

Figure 1. Conceptual research model

According to this model, this study examines the direct impact of the IFRS adoption on the financial performance of companies (H1) and the indirect impact of this adoption by mediatization the cost of capital (H2).

\subsection{Sample and Study Period}

This study is conducted on all French listed companies that belong to the CAC All Tradable index. This index represents the French economy and the overall evolution of the French stock market. According to Cormier et al. (2010), this is the best indicator to test the effects of adopting IFRS as it reflects the diversity of the application of the international repository.

French accounting standards differ widely from IFRS. As a result, there has been a profound change in financial information following the adoption of the international standards. Ding et al. (2007) provide that the study of the French context makes it possible to clearly identify the effect of the adoption of IFRS and to generalize the results on all companies in Europe.

Examining the impact of IFRS by taking as a sample a single country attempts to eliminate any statistical bias associated with the use of international samples on the one hand and to eliminate any impact of differences in institutional environments prior to the adoption of IFRS on the other hand. In addition, companies in the financial sector (Global Industry Classification Standard) which include insurance companies, credit institutions and banks are discarded because of their accounting and financial specificities. According to Urquiza et al. (2012), the incorporation of these firms into the sample may bias the results. The number of enterprises making up the final sample is thus reduced to 87 enterprises. The sectoral distribution of the sample is presented in Table 1.

Table 1. Distribution of the final sample by sector of activity

\begin{tabular}{lll}
\hline Sector of activity & Nb of companies & Percentage \\
\hline Oil and Gas & 4 & 4.598 \\
\hline Basic Materials & 2 & 2.299 \\
\hline Industries (capital goods, industrial services, building materials) & 23 & 26.437 \\
\hline $\begin{array}{l}\text { Consumer goods (Automobiles, Agri-food, household products, } \\
\text { cosmetics ...) }\end{array}$ & 18 & 20.690 \\
\hline Health (health equipment and services, pharmacy, and biotechnology) & 4 & 4.598 \\
\hline Telecommunications & 1 & 1.150 \\
\hline Consumer services (distribution, media, leisure ...) & 18 & 20.690 \\
\hline Technology (computer software and services, information technology) & 17 & 19.538 \\
\hline Total & 87 & $100 \%$ \\
\hline
\end{tabular}

This study covers an 11-year period from 2002 to 2012, while excluding the transition year. Several researchers consider the transition year that of the first year of the mandatory adoption of IFRS 2005 (Jones and Finley 2010, Jiao et al., 2012). Some consider the transition year is the year that precedes the year of the mandatory adoption namely 2004 (Saadi, 2010). Other research considers both 2004 and 2005 as transition years ( $\mathrm{Li}, 2010)$. 
According to Saadi (2010), executives manage their results more in 2004 to avoid any significant variation following the IFRS adoption. In addition, in 2004, several companies produced financial statements in local standards and IFRS, which could make investor decision-making more difficult. Therefore, 2004 was considered in this study as a transitional year and was discarded.

The choice of a lengthy period of study makes it possible to take into account changes in accounting standards (transition to IFRS) and to have recoil on each of the two repositories (Two years under French standards and eight years under IFRS). It also eliminates the bias associated with the period of change in standards (by excluding 2004) and the bias associated with the learning and understanding period of IFRS that changes from one company to another depending on the degree of familiarity of executives and financial analysts with IFRS.

Observations with missing or aberrant data and those for which the forecast for the second subsequent year is lower than the forecast for the first subsequent year are eliminated. Therefore, the final sample for this study is 277 observations.

The necessary data were taken from three databases: stock market data from Datastream, those of financial analysts' forecasts from I / B / E / S and those of annual reports from Worldscope.

\subsection{Statistical Method Used}

To test the hypotheses formulated above, the statistical method of structural equations (SEM) was applied. This method corresponds to the second generation of data analysis tools (Fornell, 1987) and is generally used to estimate models of complex relationships between several endogenous variables and several exogenous variables.

SEM is the only method that allows the inclusion of latent variables in the research model. In addition, its contribution compared with regression methods resides mainly in the number of endogenous variables and the nature of the variables used. According to Akrout (2010), regression methods estimate the effect of several observable variables on a single observable variable. These variables are directly observable and do not imply any measurement error.

One of the advantages of SEM is that it allows testing a complex model by the presence of mediating variables. This method makes it possible to estimate at the same time the direct effects (absence of effect of the mediating variable) and the total effect (importance of the mediating variable).

Two reasons explain the use of SEM in this study. First, financial performance is a variable that has several measurement indicators. Second, verifying the indirect effect of IFRS on financial performance requires the inclusion of the mediating variable, the cost of capital.

\subsection{Definitions and Measures of Variables}

To perform this study, we selected three variables: financial performance (dependent variable), IFRS (independent variable) and the cost of capital (mediator variable).

\section{* Dependent variable: Financial performance}

Previous works have largely measured this concept through stock market measures for many reasons. These measures provide a perception of future performance, capture the risk and return dimensions, take into account the particularities of the industry and allow the assessment of management decisions. They are less likely to be manipulated by internal managers, less sensitive to accounting choices, reported objectively and easily obtainable for listed firms. Three ratios were selected to measure financial performance in this study, namely the Marris ratio, the Tobin $\mathrm{Q}$ ratio and the $\mathrm{PER}$ ratio.

- The Marris ratio is the ratio of the firm's market capitalization to the book value of equity used by Charreaux (1991) and Omri (2003)

Marris = Market capitalization / book value of equity

- The ratio of Q Tobin is the ratio of the market value of the firm to the asset replacement value used by Charreaux (1991) and Mard et al. (2014).

Due to the lack of information necessary to calculate the market value of the company and the difficulty of calculating the replacement value of assets, the new approximation of Q Tobin is as follows:

$\mathrm{Q}$ Tobin $=$ Book value of debt and equity / Book value of assets

- The PER ratio is the ratio of the stock share price to earnings per share used by Pava and Krausz (1996).

PER $=$ Share price $/$ Earnings per share 
* Independent variable: IFRS

This variable is a binary variable that captures the effect of the mandatory adoption of international standards (IFRS) in the European Union from 2005. It takes 1 for the post-IFRS observations (after 2005) and 0 for those pre-IFRS (before 2005).

* Mediator variable: Cost of capital

The cost of capital variable was interposed in this study to verify whether the impact of IFRS on the financial performance of companies results from their effect on the cost of capital. It represents the mediator variable introduced. This cost represents the required return on the different types of funding. According to Urquiza et al. (2012), the calculation of this cost poses a major problem. In order to measure this cost, the Easton formula (2004) of the implicit cost of equity, widely adopted by previous works, notably those of Li (2010), Urquiza et al (2012), Kim et al. (2013) and Nahar et al. (2016), was used. According to these authors, the calculation proposed by Easton (2004) is a robust measure of the cost specific to the company.

$$
\mathrm{COC}=\sqrt{\frac{(\text { eps2-eps1) }}{\mathrm{P} 0}}
$$

Where: eps2 and eps1 refer to earnings per share forecasts of 2 and 1 year ahead,P0 is the current price,and the $\mathrm{COC}$ is the proxy used for the cost of capital.

\section{Presentation and Interpretation of Results}

To apply SEM, we chose AMOS software (Analysis of MOment Structures) as a tool. It is a computer program for analyzing structural equations. It is created by Arbuckle (1997) and characterized by the ease of use of its graphical interface (Kline, 1998).

\subsection{Adjustment Indices}

* Model adjustment indices without the mediating variable

Table 2 presents the values of the various model adjustment indices before the introduction of the mediating variable, cost of capital.

Table 2. Adjustment indices found (Direct model, without the mediating variable)

\begin{tabular}{lllllll}
\hline GFI & AGFI & RMSEA & NFI & TLI & CFI & Normed Chi2 \\
\hline 0.995 & 0.975 & 0.040 & 0.975 & 0.975 & 0.992 & 1.447 \\
\hline
\end{tabular}

The table shows that the GFI (0.995), AGFI (0.975) indices have values greater than 0.9 and very close to 1 . In addition, RMSEA (0.040) is less than 0.05. Using these indices classified as absolute indices, we were able to verify the similarity between the theoretical model and the observed data.

The second type of indices that make it possible to compare the model tested and the reference model is called incremental indices. The NFI, the TLI and the CFI belong to this second type. The values found for these indices are respectively $(0.975),(0.975)$ and $(0.992)$. These three values are greater than 0.9 and very close to 1 thus verifying the thresholds of empirical acceptance.

The last type of indices is that of parsimony indice which makes it possible to obtain a simpler model with a better fit. The indice of parsimony is that of normed chi2. Table 2 shows that the normed chi 2 of the model tested is 1,447 , less than 2 .

The examination of the various indices reveals that the values found are satisfactory witch making it possible to deduce the good fit of the tested model to the observed data.

* Adjustment indices of the model containing the mediating variable

Table 3 shows the values of the various adjustment indices of the full model after the introduction of the cost of capital variable. 
Table 3. Adjustment indices found (model containing mediating variable)

\begin{tabular}{lllllll}
\hline GFI & AGFI & RMSEA & NFI & TLI & CFI & Normed Chi2 \\
\hline 0.990 & 0.961 & 0.055 & 0.946 & 0.934 & 0.974 & 1.845 \\
\hline
\end{tabular}

Table 3 shows that the GFI (0.990), AGFI (0.961) indices are greater than 0.9 and very close to 1 . The RMSEA (0.055) is less than 0.08. The NFI, the TLI and the CFI are respectively of (0.946), (0.934) and (0.974). These three values are greater than 0.9 and very close to 1 . The parsimony indice of normed chi2 is 1.845 , less than 2 .

Examination of the various adjustment indices of this model shows that all the values obtained are satisfactory and are at acceptable thresholds. Thus, the good fit of the global model tested to the observed data is confirmed.

\subsection{Direct and Indirect Effect of the IFRS Mandatory Adoption on the Companies' Financial Performance}

The judgment of the causal links between the IFRS, cost of capital and financial performance is achieved by verifying the value of the student test and of the significance of the relationship obtained by AMOS. The results are shown in Table 4.

Table 4. Significance of causal links

\begin{tabular}{|c|c|c|c|c|}
\hline Causality & Student's test & Estimation & $\mathrm{P}$ & Hypothesis \\
\hline \multicolumn{5}{|l|}{ Without mediating variable } \\
\hline IFRS $\longrightarrow$ Financial performance & 1.514 & 0.112 & 0.130 & $\mathrm{H}_{1}$ Rejected \\
\hline \multicolumn{5}{|l|}{ With mediating variable } \\
\hline$\longrightarrow$ Financial performance & 0.987 & 0.068 & 0.324 & \multirow{3}{*}{$\mathrm{H}_{2}$ Accepted } \\
\hline IFRS $\longrightarrow$ Cost of capital & -2.045 & -0.122 & $0.041^{*}$ & \\
\hline Cost of capital $\longrightarrow$ Financial performance & -3.395 & -0.275 & $0.000^{*}$ & \\
\hline
\end{tabular}

* Significant at $5 \%$

The table above shows that the values of the Student's tests for the indirect effect are greater in absolute values to 1.96 and the probability levels are significant at the 5\%. However, the Student's value of the direct effect is 1.514 and its probability level is not significant (0.130). Moreover, the mandatory adoption of IFRS does not have a significant direct effect on the companies' financial performance.

The direct relationship between IFRS and financial performance is examined using the model that links IFRS to financial performance without introducing the variable of capital cost. The estimation coefficient obtained is $(0.112)$ and its significance is (0.130). Hence, the mandatory adoption of IFRS has no significant direct effect on the financial performance of French companies; this allowed rejecting the first hypothesis.

The results also show that the coefficients for estimating the effect of IFRS on the cost of capital and the cost of capital effect on financial performance are negative and significant at the 5\% threshold. This confirms that the adoption of IFRS improves the financial performance of companies indirectly by the cost of capital, thus confirming the second hypothesis.

Table 5 provides estimates of the direct, indirect and total link between IFRS and financial performance.

Table 5. IFRS effects on financial performance

\begin{tabular}{lllll}
\hline Causal link & & Direct effect & Indirect effect & Total effect \\
\hline IFRS $\longrightarrow$ & Financial performance & 0.068 & 0.033 & 0.101 \\
\hline
\end{tabular}

The significance of direct and indirect relationships between IFRS and financial performance is presented in Table 6 . 
Table 6. Significance of direct and indirect links between IFRS and financial performance

\begin{tabular}{llll}
\hline Causal link & Direct without mediation & Direct with mediation & Indirect \\
\hline IFRS $\longrightarrow$ Financial performance & 0.130 & 0.324 & $0.029^{*}$ \\
& Not Significant & Not significant & Significant
\end{tabular}

$*$ Significant at 5\%

This table shows that the indirect effect of the IFRS adoption on the companies' financial performance through the cost of capital is significant at the $5 \%$ threshold. This significance is equal to (0.029).

\subsection{Results Discussion}

The findings suggest that there is no a direct link between the mandatory adoption of IFRS and financial performance. In fact, this result is not surprising. It can be attributed to the main objective of these standards. IFRS aims to improve the quantity and quality of disclosed accounting information. This improvement affects the accounting measures of financial performance that are based on accounting numbers produced and not the financial performance. Indeed, these standards have no direct impact on the company's future growth opportunities. However, the results show that the mandatory adoption of IFRS has an indirect effect on the financial performance of companies. This effect follows from the introduction of the cost of capital mediator variable.

The demonstrated indirect effect consists of two effects: the first is that of IFRS on the cost of capital and the second is that of the cost of capital on the companies' financial performance.

The significance and negativity of the first effect suggest that the adoption of IFRS leads to a significant reduction in the capital cost. In fact, the reduction in the cost of capital resulting from the IFRS mandatory adoption reflects an improvement in the informational content of the published accounting figures. This improvement leads to an improvement in the level of investor confidence in the accounting figures produced after the application of IFRS, thereby reducing the companies' cost of capital.

In addition, the results show that the effect of the cost of capital on financial performance is negative and significant at the 5\% threshold. Thus, any reduction in the cost of capital leads to a significant improvement in financial performance. These results are similar to those of Tashfeen and Liton (2010) and Mahamed and Saad (2012). Nevertheless, they are contradictory to those found by Rehman and Zaman (2011).

The impact of the cost of capital on financial performance is explained by the relationship between the cost of capital and the level of risk perceived by investors. The reduction in risk, which results from the reduction in the cost of capital, improves the level of investor confidence and reduces their level of uncertainty regarding the financial position of the firm witch resulting in an increase in the number and size of the firm's investments. Consequently, an improvement in the financial performance of the company occurs. In other words, the improvement in performance is the result of a reduction in the level of risk perceived by investors in the activities of the company following the reduction of the latter's cost of capital. The investor will be more certain of the financial situation of the company when its cost of capital decreases, which encourages him to invest more.

The cost of capital indicates the company's opportunity cost. It represents the minimum profitability expected. It refers to the level of profitability necessary for the company to maintain its value. Beyond this cost, the targeted performance can be improved by creating value. Thus, the valuation of the company and the appreciation of its value creation process are based essentially on this cost. Investors are all the more interesting and value-creating when their performance is greater than this cost. The important role of this cost in the process of creating value of the company allows it to affect the financial performance of the company.

In addition, the cost of capital reflects the risk of bankruptcy faced by the company. The increase in this cost indicates an increase in this risk and reflects the delicate situation of the company. This situation is due to the difficulty of raising capital once again to finance new projects and to seize new opportunities for growth, thus affecting the financial performance of the firm.

\section{Conclusion}

The relationship between IFRS and financial performance has not been sufficiently studied in previous literature. There is a very limited number of researches in this subject. From then, the objective of this study is to verify the direct and indirect impact of the mandatory adoption of IFRS on the financial performance of companies. The latter 
was measured by the Marris ratio, the Q Tobin ratio and the PER ratio. The indirect effect of this adoption was examined by introducing a mediating variable, which is the cost of capital.

By focusing in the French context and applying the method of structural equations using the AMOS software, the results show that the mandatory adoption of IFRS has no direct significant effect on the financial performance of companies. However, it improves this performance indirectly through their effects on the cost of capital.

The indirect effect of the mandatory adoption of IFRS on financial performance through the cost of capital arises from two effects, the effect of IFRS on the cost of capital on the one hand and the effect of the cost of capital on financial performance on the other hand.

The first effect is mainly attributed to the informational superiority of the accounting numbers produced under this international repository. However, the second effect is explained by the relationship between the cost of capital and the level of risk perceived by investors. Reducing this cost reduces investor uncertainty, which encourages them to invest more, thereby improving the financial performance of the company.

The results of this study highlight the benefits of mandatory adoption of IFRS for French companies and their sustainability. They are able to encourage companies that are located within the European or other perimeter that are not obliged to adopt these new international standards to apply them voluntarily. However, the study of one country may be considered the main limit of this study.

It would be interesting to extend this study by expanding the sample by integrating other countries. In addition, the results highlight the need for more exploration of the effects of IFRS on the stock market. In other words, does improving the financial performance of firms have an effect on the overall performance of the stock market?

\section{References}

Akrout, F. (2010). Les méthodes des Equations Structurelles. Tunis: Imprimerie Coopi.

Arbuckle, J. (1997). Amos Users' Guide Version 3.6. Chicago: Smallwaters Corporation.

Barneto, P., \& Gregorio, G. (2011, May). Normes IFRS et mesure de la performance. Étude comparative auprès des établissements bancaires européens. Comptabilités, Economie et Société, Montpellier.

Barth, M. E., Landsman, W., \& Lang, M. (2008). International Accounting Standards and accounting quality. Journal of Accounting Research, 46(3), 467-498.https://doi.org/10.1111/j.1475-679X.2008.00287.x

Beranova, M., \& Polak, J. (2014). Changes in View on Financial Position and Performance of a Company at Application of the IFRS in the Czech Republic. ActaAcademicaKarviniensia, 14(1), 16-23. https://doi.org/10.25142/aak.2014.002

Beuren, I. M., Hein, N., \& Klann, R. C. (2008).Impact of the IFRS and US-GAAP on economic-financial indicators. Managerial Auditing Journal, 23(7), 632-649. https://doi.org/10.1108/02686900810890616

Brigham, E., \& Gapenski, L. (1996). Financial Management. Dallas: The Dryden Press.

Bushman, R., \& Smith, A. (2001). Financial Accounting Information and Corporate Governance. Journal of Accounting and Economics, 32(1-3), 237-333. https://doi.org/10.1016/S0165-4101(01)00027-1

Charreaux, G. (1991). Structure de propriété, relation d'agence et performance financière. Revue économique,42(3), 521-552. https://doi.org/10.3406/reco.1991.409292

Cormier, D., Ledoux, M. J., \& Magnan, M. (2010). Le reporting de gouvernance, les attributs du conseil et la qualité des résultats comptables. Comptabilité Contrôle Audit, 16(2), 69-96. https://doi.org/10.3917/cca.162.0069

Cuijpers, R., \& Buijink, W. (2005). Voluntary Adoption of Non-local GAAP in the European Union: A Study of Determinants and Consequences. European Accounting Review, 14(3), 487-524. https://doi.org/10.1080/0963818042000337132

Daske, H. (2006). Economic benefits of adopting IFRS or US-GAAP-Have the expected cost of equity capital really decreased?. Journal of Business Finance and Accounting, 33(3-4), 329-373. https://doi.org/10.1111/j.1468-5957.2006.00611.x

Daske, H., Hail, L., Leuz, C., \& Verdi, R. (2012). Adopting a label: heterogeneity in the economic consequences around IAS/IFRS adoptions. Journal of Accounting Research, 51(3), 495-547. https://doi.org/10.2139/ssrn.1864771

Ding, Y., Hope, O., Jeanjean, T., \& Stolowy, H. (2007). Differences between domestic accounting standards and IAS: 
Measurement, determinants and implications. Journal of Accounting and Public Policy, 26(1), 1-38. https://doi.org/10.1016/j.jaccpubpol.2006.11.001

Easton, P. D. (2004). PE ratios, PEG ratios, and estimating the implied expected rate of returns on equity capital. The Accounting Review, 79(1), 73-95. https://doi.org/10.2308/accr.2004.79.1.73

Fornell, C. (1987). A second generation of multivariate analysis: Classification of methods and implications for marketing research. Working paper No.414, University of Michigan.

Ibrahim, M., \& Ibrahim, A. (2015). The Effect of SMEs' Cost of Capital on Their Financial Performance in Nigeria. Journal of Finance and Accounting, 3(1), 8-11.

Jensen, M. (1986). Agency cost of free cash flow, corporate finance and takeovers. The American Economic Review, 76(2), 323-329.

Jiao, T., Koning, M., Mertens, G., \& Roosenboom, P. (2012).Mandatory IFRS adoption and its impact on analysts' forecasts. International Review of Financial Analysis, 21, 56-63. https://doi.org/10.1016/j.irfa.2011.05.006

Jones, S., \& Finley, A. (2010). Have IFRS made a difference to intra-country financial reporting diversity?. The British Accounting Review, 41(1), 22-38. https://doi.org/10.1016/j.bar.2010.10.004

Junior, M. (2015). Impact of Convergence to IFRS on the Economic and Financial Performance of Construction and Transportation Enterprises: A Study Conducted through Data Envelopment Analysis. Applied Mathematical Sciences, 9(91), 4499-4521. https://doi.org/10.12988/ams.2015.53193

Kebewar, M. (2012). La structure du capital et la profitabilité: Le cas des entreprises industrielles françaises. Document de travail. Laboratoire d'économie d'Orléans.

Khaled, A. M. A., \& Samer, F. O. (2013). Impact of Cost of Capital, Financial Leverage and the Growth Rate of Dividend on Return on Investment.An Empirical Study of Amman Stock Exchange. International Journal of Academic Research in Economics and Management Sciences, 2(4), 59-69. https://doi.org/10.6007/IJAREMS/v2-i4/65

Kim, J. B., Shi, H., \& Zhou, J. (2013). International Financial Reporting Standards, institutional infrastructures, and implied cost of equity capital around the world. Review of Quantitative Finance and Accounting, 42(3), 469-507. https://doi.org/10.1007/s11156-013-0350-3

Kim, S., \& Ryu, H. (2018). The impact of mandatory IFRS adoption on capital markets: evidence from Korea. International Journal of Accounting \& Information Management, 26(1), 35-58. https://doi.org/10.1108/IJAIM-05-2016-0049

Kline, R. B. (1998). Principles and practices of structural equation modeling. New York: Guilford.

Kochhar, R. (1996). Explaining Firm Capital Structure: The Role of Agency Theory vs. Transaction Cost. Economics $\begin{array}{lcr}\text { Strategic Management } & \text { Journal, } & 17(9) \text {, } \\ \text { https//doi.org/10.1002/(SICI)1097-0266(199611)17.9<713*.AID-SMJ844>3 } 0 . \text { CO } \cdot 2-9\end{array}$

Lahmini, H. M. (2015). Impact de la décision de financement sur la performance de l'entreprise marocaine : Cas des sociétés cotées des secteurs Immobilier et Matériaux de Construction. Colloque et séminaire doctoral international sur les méthodes de recherche, Juin, Lyon.

Lainez, J., \& Callao, S. (2000). The Effect of Accounting Diversity on International Financial Analysis: Empirical Evidence. The International Journal of Accounting, 35(1), 65-83. https://doi.org/10.1016/S0020-7063(99)00030-8

Li, S. (2010). Does Mandatory Adoption of International Financial Reporting Standards in the European Union Reduce the Cost of Equity Capital?. The Accounting Review, 85(2), 607-636. https://doi.org/10.2308/accr.2010.85.2.607

Lima, G., Gois, A., \& Sousa, N. (2018).The Effect of National Culture on the Relationship between IFRS Adoption and the Cost of Equity Capital. Journal of International Accounting Research.

Mard, Y., Marsat, S., \& Roux, F. (2014). Structure de l'actionnariatet performance financière de l'entreprise: le cas français. Finance Contrôle Stratégie, 17(4), 59-83. https://doi.org/10.4000/fcs.1559

Modigliani, F., \& Miller, M. H. (1958). The Cost of Capital, Corporation Finance and the Theory of Investment. American Economic Review, 48(3), 261-297. 
Mohamed, N. E. A., \& Saad, N. (2012). Cost of Capital-The Effect to Firm Value and Profitability Performance in Malaysia. International Journal of Academic Research in Accounting, Finance and Management Sciences, 2(4), 353-361.

Nahar, S., Azim, M., \& Jubb, C. A. (2016). Risk disclosure, cost of capital and bank performance. International Journal of Accounting and Information Management, 24(4), 476-494. https://doi.org/10.1108/IJAIM-02-2016-0016

Omri, A. (2003). Systèmes de gouvernance et performance des entreprises tunisiennes. Revue Française de Gestion, 142, 85-100. https://doi.org/10.3166/rfg.142.85-102

Pastor, L., Sinha, M., \& Swaminathan, B. (2008).Estimating the Intertemporal RiskReturn Tradeoff Using the Implied Cost of Capital. The Journal of Finance, 63(6), 2859-2897. https://doi.org/10.1111/j.1540-6261.2008.01415.x

Pava, M. L., \& Krausz, J. (1996). The association between Corporate Social Responsibility and Financial Performance: the paradox of social cost. Journal of Business Ethics, 15(3), 321-357. https://doi.org/10.1007/BF00382958

Pouraghajan, A., Tabari, N. A. Y., Ramezani, A., Mansourinia, E., Emamgholipour M., \& Majd, P. (2012). Relationship Between Cost of Capital and Accounting Criteria of Corporate Performance Evaluation: Evidence from Tehran Stock Exchange. World Applied Sciences Journal, 20(5), 666-673.

Rehman, M. A., \& Zaman, Q. (2011). Does corporate performance predict the cost of equity capital?. American Journal of Social and Management Sciences, 2(1), 26-33. https://doi.org/10.5251/ajsms.2011.2.1.26.33

Saadi, T. (2010). Création de valeur : l'impact des normes IFRS sur le contenu informationnel du résultat net : le cas de la France. La place de la dimension européenne dans la Comptabilité Contrôle Audit, Strasbourg.

Sahut, J. M.,\& Souissi, M. N. (2007). L'impact des normes IFRS sur la performance et le risque des compagnies d'assurance. Colloque Comptabilité et environnement, Mai, Poitiers.

Simerly, R., \& Li, M. (2000). Environmental dynamism, capital structure and performance: a theoretical integration and an empirical test. Strategic Management Journal, 21(1), 31-49. https://doi.org/10.1002/(SICI)1097-0266(200001)21:1<31::AID-SMJ76>3.0.CO;2-T

Šteker, K., \& Otrusinová, M. (2011). The current state of the application of international accounting standards in the Czech Republic. Recent Researches in Social Science, Digital Convergence, Manufacturing \& Tourism.

Swanson, Z. L., \&Viinanen, V. (2006). Does the Weighted Cost of Capital Associate with Returns on Operating and Financial Assets with Investor Anticipation or Reaction? (And Do Operating and Financial Assets Have Synergy?). Research paper, Kansas State University. https://doi.org/10.2139/ssrn.1030387

Taiwo, F. H., \&Adejare, A. T. (2014). Empirical Analysis of the Effect of International Financial Reporting Standard (IFRS) Adoption on Accounting Practices in Nigeria. Archives of Business Research, 2(2), 1-14. https://doi.org/10.14738/abr.22.43

Tashfeen, H., \& Liton, C. (2010). Is The Cost of Capital an Important Determinant of Market Performance of Private Commercial Banks in Bangladesh?. The American Society of Business and Behavioral Sciences Annual Conference, 17(1), 389-399.

Tort, E., \& Escaffre, L. (2012). Améliorer l'information financière en IFRS. Paris: Dunod.

Tweedi, D. (2006). The Statement prepared by David Tweedie, Chairman of the International Accounting Standards Board, before the Committee on Economic and Monetary Affairs of the European Parliament.

Unobong, A. A. (2015). IFRS Adoption and Firms Performance: A Comparative Analysis of Quoted Food and Beverage Manufacturing Firms in Nigeria. European Journal of Accounting Auditing and Finance Research, $3(8), 70-83$.

Urquiza, F., Abad Navarro, M., \& Trombetta, M. (2012). Disclosure Strategies and Cost of Capital, Managerial and Decision Economics, 33(7-8), 501-509. https://doi.org/10.1002/mde.2562

\section{Note}

Note 1. Cited by Tort and Escaffre (2012) 